\title{
The Effect of Teacher Performance on Student's Productive Competencies in Vocational High School
}

\author{
Ramli \\ Faculty of Engineering State University of Padang, INDONESIA \\ Jalan Prof. Dr. Hamka Air Tawar, Padang, 25131, Indonesia +62 7527055644 \\ ramli_bakar76@yahoo.com
}

\begin{abstract}
This study was aimed to reveal the achievement level of (1) the teacher performance of vocational school students, (2) the productive competencies of vocational school, and (3) the effect of teacher performance on productive competencies of West Sumatra vocational schools students. The study used is the descriptive quantitative method. The number of population of 3.578 students. The sample, consisting of 160 students, was taken by using the multistage random sampling technique. The data, collected using a questionnaire and documentation, were analyzed using the descriptive and inferential analyses. The study found: (1) the teacher performance of vocational school was in good category, (2) productive competencies of student were in the good category, (3) there was a positive and significant influence of the teacher performance on the productive competencies and (4) the principal must monitor the performance of teachers through classroom observation and laboratory.
\end{abstract}

Index Terms - teacher performance, productive competencies, vocational students.

\section{Introduction}

Educational success is essentially influenced by many factors, among others: teachers, learners, curriculum, facilities, and environmental education. Teachers occupy a very important position in learning activities at school, without neglecting other supporting factors. Teacher education as a subject largely determines the success of education. The teacher is spearheading directly related to the learner as subject and object of learning [1]. The implementation of the curriculum, demanding teacher performance in providing learning experiences that can improve the competence of learners, because the success or failure depends on the touch learning, activity, creativity and performance of teachers as spearhead the implementation of a curriculum.

The teacher is a major factor in the educational process. Although complete and advanced educational facilities, but if it is not supported by the presence of teachers who are competent and qualified, then the impossible will lead to maximum learning process. Productive in vocational learning will be influenced by the quality of the learning process in the classroom, workshops and laboratories. Therefore, to increase the productive competence of learners, learning process in the classroom, workshops and laboratories should take place with good, efficient and effective. The learning process will take place properly if it is supported by teachers who have the competence and good performance.

Efforts to increase the productive competence vocational learners in accordance with the demands of the workplace, based on the need to improve the quality of learning in the classroom. Therefore, the learning process in the classroom must be going well, efficient and effective manner. The learning process will take place properly if it is supported by teachers who have the competence and good performance. Teachers who have a good performance, can improve morale and motivation of learners, which in turn will improve the productive competence. It should be recognized that the teacher is a major factor in the educational process. Although the facility is complete and advanced education, but if it is not supported by the presence of qualified teachers, then it is impossible to inflict maximum learning. $76.6 \%$ of learners' learning outcomes are influenced by the performance of the teacher [2].

Performance is defined as the record of outcomes produced on a specified job function or activity during a specific time period [3]. In general it can be concluded that the performance of teachers is teacher performance meaningful work in the process of learning that teachers carry out the learning interaction between teachers and learners. The performance of teachers is an ability possessed by an individual to do a job, so the job looks achievement in reaching the goal [4]. The performance of a skill or proficiency of teachers in creating an atmosphere of communicative learning between teachers and learners that includes cognitive, affective and psychomotor [5].

The work of a teacher who displayed a series of capabilities as a professional teacher. The teacher performance is the performance of teachers in performing their duties as educators [6]. The performance of teachers in designing teaching programs that must be passed by a planning professional teacher is teaching or in other words, also known as designing teaching programs [7]. In general it can be concluded that the performance of the teacher learning process meaningful work carried out in the teachers' instructional interactions between teachers and learners.

Law No. 20 of 2003 on National Education System Article 15 states that vocational education is secondary education that prepares students primarily for work in a particular field [8]. According to Government Regulation No. 19 of 2005 on National Education Standards Article 26, paragraph 3 Competency Standards a secondary vocational education aims to improve intelligence, knowledge, personality, noble character and skills for learners to live independently and to follow further education in accordance with its vocational programs [9]. In line with that, a picture of productive graduates of vocational competencies extracted from Finch and Crunkilton, that: The quality of vocational education applying double size, ie according to the size of the school or the quality of in-school success standards and quality according to the size of the community 
or out-standards of school success [10]. The first criteria include aspects of student success in meeting the curricular demands that have been oriented towards the demands of the working world, while the second criteria, including the success of students in performance capabilities in accordance with national and international competency standards once they are in actual employment.

The productive competence, referring to the Indonesian National Competence (SKKNI) existing or agreed as a reference, in certain industry standards that become industry partner. This competence can be achieved by education and training approach which refers to the criteria of expertise the business / industry achievement through training in the production process or use the production process as a vehicle for learning. This training can take place in the industry, through the direct involvement of learners in the process of production, or in schools through the involvement of learners in the learning process productive and production processes in the school production units.

The competency demonstrated ability to apply knowledge, understanding, or skills assumed to contribute to success in life [11]. The unit of competency in education further means the possession and development of sufficient skills, attitudes and experience for successful performance in life roles. The competence is the capacity to perform special activities will always entail some combination of knowledge skills/ disposition/values which when analysis almost always looks like some combination of generic or key competencies [12].

Implied that the essence of the definition of competence is the ability of students to apply all of the subject matter in their lives, not just mastery of the course material. Competence that allows students capable of acting well in his life. Another essence of the definition is a learning experience as an important element of competence. Experience was formed from the integration of knowledge, skills, and attitudes contained in each subject. Results of integration that must be transformed into a learning experience that will cumulatively develop into competence skills that make students successful in his work and his personality is reflected in [13]. In other words, the provision of competency, students can live successfully in the community (productive competence or life skills), professional in his work (vocational competence), and is able to develop itself (productive competence). one form of development that he is not only able to: (1) perform work or profession, but also capable of (2) to transfer and develop it into a task or a new situation, and can (3) to continue to develop his or her own studies.

Thus, productive competence focus on individual development of each student who is certified vocational high schools based on their performance in all aspects of the skills in the community rather than simply have passed a set of subjects based on the results of measurements of the acquisition of knowledge without regard to the ability of applied knowledge [14]. That is, the target productive competence focuses on the development of the student can not do (the knowing) be can do (the doing and behaving) [15]. Therefore, productive competence define the ways that must be taken so that most students have a minimum competency required. Emphasis on achieving specific productive competence will encourage students to be more scalable, and specific plan, implement, and evaluate themselves in order to make it clear that students can attain a certain minimum of competency standards.

Generally, learning in productive competence in vocational schools focused on one or more types of the following competencies: (1) the development of behavioral work, (2) the performance of a holistic personality fit the norm, and (3), functional competence in performing the role or profession in the community. The learning in productive competence in the three types of the three levels of education: (1) basic skills (basic skills) in primary and secondary education; (2) skills (life skills role) at the school for adults, and (3) generic skills (generic skills) at the postsecondary [16].

Based on the description that has been stated above, the purpose of this study was to describe: (1) the extent to which teacher performance on Vocational high school in an effort to increase the productive competence?, (2) the extent to which the productive competence on Vocational high school in West Sumatra?, (3) whether there is effect teacher performance on productive competence of vocational high school students in West Sumatra?

\section{Research Methods}

This study uses quantitative descriptive correlation approach, which is a technique designed to determine how much influence the independent variables with the dependent variable. The independent variable is the dependent variable of teacher performance and productive competence of vocational high school students. The study population was all students of vocational high school in West Sumatra class $\mathrm{XI}$, as many as 3.578 people. Sampling was done by multistage random sampling technique. The first step, namely the selection of two vocational schools in the cluster, each type of Vocational high school based on the location in the city and in the district, and elected Vocational high school 2 Payakumbuh and Vocational high school 1 Lintau Buo Tanah Datar. The second step, based on data from two vocational high schools were selected sample of 160 randomly (simple random), as many as 80 people from high school vocational 2 Payakumbuh and 80 people from high school vocational 1 Lintau Buo Tanah Datar.

Data collection tool of teacher performance a questionnaire developed by researchers Likert scale models with the following steps (1) construct the lattice according to the indicators of each variable. (2) preparing the grains statements based indicators of each variable, and (3) test, which tests the validity and reliability testing with a number of respondents as the trial of 30 people. Validity test is done with the Pearson Product Moment correlation analysis and reliability test using Alpha Cronbach formula $(\alpha)=0.05$. In testing the validity, significance level determined Point declaration is valid, if the product moment correlation coefficient or $r$ count is greater than $r$ table, corresponding predetermined significance level. Experimental results show that the reliability coefficient of 0.94 . The criteria used to establish the reliability of the instrument is if the reliability coefficient greater than or equal to 0.50 [17].

Data analysis was performed by an analysis of descriptive and inprential. Requirements that must be met prior to analysis and hypothesis testing, namely, (1) test for 
normality, and (2) a homogeneous test. For normality testing done with the Lilliefors test, and for homogeneity of variance test conducted by the Bartlett test.

\section{Results and Discussion}

\section{A. Teacher Performance}

Based on data of teacher performance teacher performance score, it was obtained that the range of empirical scores was 96; with the lowest score 153 and the highest score 249. Based on data analysis, it is obtained that the average value is 193.13, standard deviation 22.00, median 192.00 , mode 203 , the number of grade 8 , and length grade 12 as well as the length frequency distribution as shown in Table 1 below.

Table 1 Frequency distribution score teacher performance

\begin{tabular}{cccc}
\hline Number. & Class Interval & $\begin{array}{c}\text { Absolute } \\
\text { Frequency }\end{array}$ & $\begin{array}{c}\text { Relative Frequency } \\
(\%)\end{array}$ \\
\hline 1. & $237-249$ & 5 & 3.13 \\
2. & $225-236$ & 7 & 4.38 \\
3. & $213-224$ & 21 & 13.13 \\
4. & $201-212$ & 34 & 21.88 \\
5. & $189-200$ & 26 & 16.25 \\
6. & $177-188$ & 19 & 11.25 \\
7. & $165-176$ & 28 & 17.5 \\
8. & $153-164$ & 20 & 12.5 \\
\hline & Total & 160 & 100.00 \\
\hline
\end{tabular}

Based on the calculations shown in Table 1, it appears that most of the teachers reported having a good performance, however, there is still 12.5 percent teachers have low performance

\section{B. Competence Productive}

Based on productive competence scores, it is obtained that the range of empirical score was 26.70; the lowest score was 70.70 and the highest score was 97.40. The results of the analysis of the data showed an average score of 83.53 , standard deviation 5.62, median 82.91, mode 80.00, the amount of class 8 and class length 3.5 and frequency distribution as shown in Table 2 below.

Table 2. Frequency distribution of productive competence scores

\begin{tabular}{cccc}
\hline Number & Class interval & $\begin{array}{c}\text { Absolute } \\
\text { frequency }\end{array}$ & $\begin{array}{c}\text { Relative } \\
\text { frequency } \\
(\%)\end{array}$ \\
\hline 1. & $70.70-74.19$ & 3 & 1.88 \\
2. & $74.20-77.69$ & 22 & 13.75 \\
3. & $77.70-81.19$ & 28 & 23.75 \\
4. & $81.20-84.69$ & 30 & 18.75 \\
5. & $84.70-88.19$ & 31 & 19.38 \\
6. & $88.20-91.69$ & 25 & 15.62 \\
7. & $91.70-94.19$ & 7 & 4.38 \\
8. & $94.20-97.70$ & 4 & 2.50 \\
\hline \multicolumn{5}{r}{ Total } & 160 & 100 \\
\hline
\end{tabular}

Based on Table 2, it can be seen that that most students good acquire productive competence. Nevertheless, there is still a small fraction of students needs to be improved their productive competence. Furthermore, based on the results of a simple linear regression analysis on pairs of data between learning motivation variable $(\mathrm{X})$ to the productive competence $(\mathrm{Y})$, it produces direction of the regression coefficient $b$ of 0.086 and a constant of 66.863 . Thus, the shape of the influence of these two variables can be expressed by the regression equation $\mathrm{Y}=66.863+0.086 \mathrm{X}$. Before being used for predictive purposes, the regression equation is linear and must be eligible means. To determine the degree of significance, the regression equation F-test is then performed as in Table 3 below:

Table 3. ANOVA for linearity test significance and simple linear regression

\begin{tabular}{|c|c|c|c|c|c|c|}
\hline $\begin{array}{l}\text { Variance } \\
\text { Source }\end{array}$ & $\mathrm{df}$ & JK & RJK & $F_{\text {test }}$ & $\begin{array}{c}F_{\text {table }} \\
\alpha=0,05\end{array}$ & $\begin{array}{l}F_{\text {table }} \\
\alpha=0,01\end{array}$ \\
\hline Total (T) & $\begin{array}{c}16 \\
0\end{array}$ & 1121633 & - & - & & \\
\hline $\begin{array}{l}\text { Regression } \\
\text { (a) } \\
\text { Regression } \\
\text { (b/a) } \\
\text { rest }\end{array}$ & $\begin{array}{c}1 \\
1 \\
15 \\
8\end{array}$ & $\begin{array}{c}1116600 \\
65 \\
666,506 \\
4365,55\end{array}$ & $\begin{array}{c}- \\
666,50 \\
6 \\
27,63\end{array}$ & $\begin{array}{c}- \\
24,1 \\
23 * * \\
-\end{array}$ & 3,92 & 6,81 \\
\hline $\begin{array}{l}\text { unsuitable } \\
\text { error }\end{array}$ & $\begin{array}{l}69 \\
89\end{array}$ & $\begin{array}{c}1971,708 \\
2393,84\end{array}$ & $\begin{array}{l}28,575 \\
26,897\end{array}$ & $\begin{array}{c}1,06 \\
2^{\mathrm{ns}}\end{array}$ & 1,45 & 1,68 \\
\hline
\end{tabular}

Description: $\mathrm{df}=$ degrees of freedom, $\mathrm{JK}=$ Sum of Squares, RJK = Average Number of Squares regression $* *$ highly significant $(\mathrm{F}$ test $=24.123>\mathrm{F}=6.81)$, ns $=$ nonsignificant, significant linear regression $(\mathrm{F}$ value $=1.062<\mathrm{F}$ $=1.45$ ).

Results of analysis of variance as shown in Table 3, it can be concluded that the shape of the relationship between teacher performance $(\mathrm{X})$ to the productive competence $(\mathrm{Y})$ is the mean and linear, thus the regression model can be used to predict. This regression model implies that if a teacher's performance improved the propensity score productive competence increased by 0.086 at 66.863 constants. Model of the effect of teacher performance $(\mathrm{X})$ to the productive competence $(\mathrm{Y})$ has a regression equation $\mathrm{Y}=66.863+$ $0.086 \mathrm{X}$ looks like Figure 1, below:

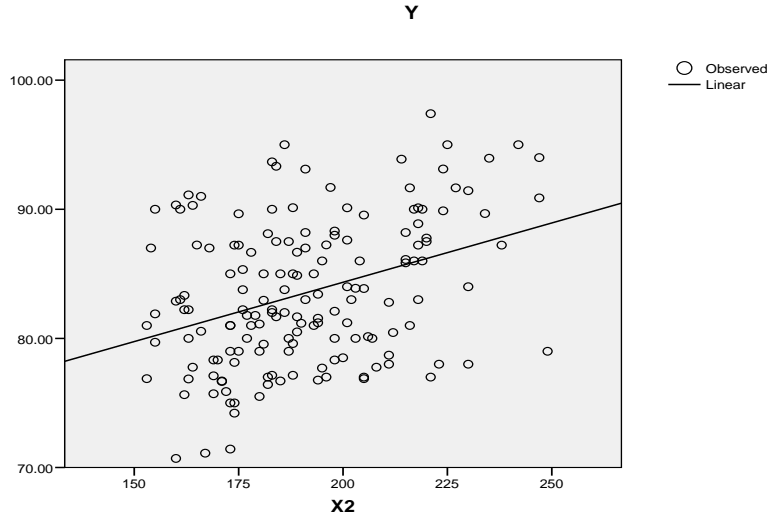

Fig. 1. Model effects of teacher performance $(\mathrm{X})$ to productive competence (Y)

Correlation analysis on pairs of data for both variables produce Product moment correlation coefficient for ry $=0.338$. and for the significance test of the correlation coefficients are presented in Table 4 this follows 
Table 4. Testing the significance of correlation coefficients teacher performance the competence of productive

\begin{tabular}{cccccc}
\hline $\begin{array}{c}\text { Correlation } \\
\text { Coefficient }\end{array}$ & $\begin{array}{c}\text { Correlation } \\
\text { Between }\end{array}$ & $\begin{array}{c}\text { Determination } \\
\text { Coefficient }\end{array}$ & $\mathrm{t}_{\text {test }}$ & $\begin{array}{c}\mathrm{t}_{\text {table }} \\
\alpha=0,05\end{array}$ & $\begin{array}{c}\mathrm{t}_{\text {table }} \\
\alpha=0,01\end{array}$ \\
\hline 0,338 & $\mathrm{X}$ and $\mathrm{Y}$ & 0,114 & $4,508^{* *}$ & 1,65 & 2,33
\end{tabular}

Description: $* *$ highly significant correlation coefficient $(4.508=\mathrm{t}$ count $>\mathrm{t}$ table $=2.33$ )

\section{Discussion}

Based on the analysis it was found that the teacher performance give positive and significant effect on the productive competence. Thus the teacher performance is one of the important variables that should be considered to improve the productive competence. This finding is in line with the results of the study conducted by Taylor \& Pearson the found that the strongest impact on achievement occurred through teacher commitment to school-community partnerships, confirming recent evidence about positive effects of such linkages in elementary [18]. States among the various inputs that determine the quality of education shown by the achievements of learners third is determined by the teacher [19].

The most dominant factor influencing teacher learning is the quality of teacher performance. Through the teacher 's performance is expected to improve the quality of education. In addition, the performance of teachers in particular should be able to increase the productive areas of the psychomotor domain, including in the arts, vocational education, and special education. Learning in the psychomotor domain involves developing a productive abilities of learners in a particular field. Teachers are very productive role in skill learning, the teacher must have qualified productive and productive field teaching authority requirements.

This finding is also in line with the opinion of Cruickshank, the performance of teachers have an immediate effect on the learning process is the performance of the teacher in the classroom or teacher performance class room [20] .This means that the teachers involved in learning activities has a good performance, will be able to improve the attitude and motivation of learners that will ultimately improve the competence students.

Performance vocational teachers are required to have a capability that is not only able to teach the theory in class, but they are required also able to educate, teach, train, and guide learners in the workplace, whether it is in the workshop, workshop, laboratory, and guiding students to afford work in the world of business and industry with a prospective career.

Reforms in the field of vocational teacher education, teacher character demanded changes that have so far used to the pattern of leadership instruction, all-round set of top, teachers lose creativity. But to be able to compete in the global era, sophisticated, era that demands a high level of adaptation to changes, require teachers who have high performance

Study the problems of vocational teacher performance, then the effort to continuously improve it should be done continuously and through various efforts. The performance is still not good to be a major concern for repair, particularly through improved teacher motivation to provide optimal service to students, providing space for students to learn to criticize, in order to master the competencies better. Generally, the students only had the opportunity to study the surface (surface learning), they should dive resulting in a high intensity learning (deep learning). Similarly, in an effort to improve the quality of teachers should be active learning me-do action research, trying to make improvements learning with a variety of learning models, to innovate in order to be effective and efficient learning. This activity is still not implemented by vocational teachers [21].

Increasing the quality of learning in the classroom, laboratory and workshop, will be able to increase the competence of learners. This is understandable because the teacher has a good performance in the class will be able to explain the lesson well, able to motivate learners to learn well, being able to use instructional media well, able to guide and direct the learners in learning, so that students will have the spirit in learning, pleased with the learning activities, and find it easy to understand the material presented by the teacher.

Critical issues related to the performance of the teacher is to provide service, guidance, and assistance to students to improve the learning process, through interaction and communication. The ability to communicate and interact is a prerequisite in the learning process. Due to communicate effectively can encourage learners' understanding of the learning content. To that end, every teacher should be equipped with effective communication skills, namely communication which gives the ability to explain and examples are more accurate with the right choice of words. Field experience shows, that the lack of mastery of teacher communication is one factor contributing to the lack of effective learning process in schools. Communication skills are also required to interact with peers and the public school environment.

Improved performance of the teacher in the learning process to have expertise in educating, teaching and training, the teachers develop themselves in order to adapt to its environment. Activities to improve the learning process can be done through peer validation. Validation peer can provide input more accurate than a real learning process. Research results and observations indicate that the coordination between teachers, teachers with special teachers have not been going well so that corrective actions that build not performing well.

In the learning process, strengthening or reinforcement is an important thing in a more powerful motivating learners. Through the learning process, educators may be possible to show a variety of behaviors with different shades. Each behavior can be categorized as acceptable behavior and unacceptable. Acceptable behavior need to be established so that the behavior will become a habit that becomes a role model for students, while the behavior is unacceptable muted, attenuated, and removed so that no longer shown. Efforts to stabilize acceptable behavior that is called reinforcement.

\section{Conclusion}

Based on the results and discussion, summarized as follows: (1) the overall performance of vocational teachers' West Sumatra is in the category of good, (2) Competence productive learners, such as skills and learning activities in 
the metal cutting process Vocational High School in West Sumatra are in either category, and (3) There is positive and significant influence on the performance of teacher competence productive learners Vocational High School West Sumatra. This means that if the teacher's performance improved, the tendency of productive competence learners will increase. The analysis showed the coefficient of determination of 0.114 . This means that $11.4 \%$ of variance explained by the variable productive competence of teacher performance.

\section{Suggestion}

Along with the conclusions, propose the following suggestions: (1) the principal must monitor the performance of teachers through classroom observation, laboratory and workshop and to gather information from students about the implementation of learning, and the results are returned to the council inform the teacher, (2) the principal must cooperate with the school superintendent and do synergistically in improving teacher performance, (3) the supervisor must have the ability to assist teachers in the classroom to solve the problem, and (4) should be done at regular meetings between principals and supervisors to discuss the achievement of the performance of teachers and how to improve it.

\section{References}

[1] Sanjaya, Wina. 2009. Strategi Pembelajaran Berorientasi Standar Proses Pendidikan. Jakarta: Prenada.

[2] Sudjana, Nana. 2002. Dasar-dasar Proses Belajar Mengajar. Bandung; Sinar Baru.

[3] Bernardin and Russell. 2000. Human Resources Management, Mc Graw Hill, New York.

[4] Nawawi, Hadari. 1996. Administrasi Pendidikan. Jakarta : PT. Gunung Agung, Cet. Ke-1,

[5] Subroto, Suryo. 1997. Proses pembelajaran. Jakarta: Rineka Cipta. Cet. Ke-1.

[6] Suharsaputra, Uhar. 2010. Administrasi Pendidikan. Bandung. PT. Refika Aditama.

[7] Nurdin, Syarifuddin. 2003. Guru Professional dan Implementasi Kurikulum. Jakarta: Ciputat Press. Cet. Ke-2.

[8] Undang-Undang Nomor 20 Tahun 2003 tentang Sistem Pendidikan Nasional. Jakarta: Departemen Pendidikan Nasional.

[9] Peraturan Pemerintah Nomor 19 tahun 2005 tentang Standar Nasional Pendidikan. Jakarta: Departemen Pendidikan Nasional

[10] Finch, Curtis R. \& Crunkilton, John R. 1984. Curriculum Development in Vocational and Technical Education: Planning, Content, and Implementation. Boston: Allyn and Bacon, Inc

[11] Parnell, D. 1978. The case for competency-based education. Bloomington, Indiana: Phi Delta Kappa Educational Foundation.

[12] Gonczi, Andrew. 2004. The New Profesional and Vocational Education. Crow Nest NSW: Allen and Unwin.

[13] Hasan, S.H. 2002. "Hakekat kurikulum berbasis kompetensi." Makalah pada Seminar Nasional Kurikulum Berbasis Kompetensi. Padang: UNP, 25 September 2002

[14] Thomson, S. 1981. "Competency-based education and secondary schools: Current practice and some implications. In Competencybased education: Beyond minimum competency testing .New York: Teachers College,Columbia University.
[15] Hall, G.E. \& Jones, H.L. 1976. Competency-based education: The process for the improvement of education. Englewood Cliff, N.J.: Prentice Hall Inc

[16] Goldhammer, K. \& Wietzel, B. 1981. "What is competency-based education?" In Competency-based education: Beyond minimum competency testing. R. Nickse \& L. McClure (Eds.) New Yok: Teachers College Press, $43-61$.

[17] Gay, L.R. 1985. Educational Evaluation and Measurement. Columbus, Ohio: Carles Publishing Company.

[18] Taylor, B. M., and Pearson, P. D. (2004). Research on learning to read at school, at home, and in the community. Elementary School Journal, 105(2), 167-182.

[19] Supriadi, Dedi. 1999. Mengangkat citra dan martabat guru. Yogyakarta: Adicita Karya Nusa

[20] Cruickshank, D.R. 1990. Research that informs teachers and teacher educators. Bloomington: Phi Delta Kappa Educational Foundation.

[21] Biggs.J.B \& Moore. P.J. 1993. The Process of Learning. Third Edition. Sydney: Prentice Hall. 